\title{
PROMETNO ONESNAŽEVANJE OZRAČJA Z DUŠIKOVIM DIOKSIDOM V LJUBLJANI
}

\section{Matej Ogrin: Prometno onesnaževanje ozračja z dušikovim dioksidom v Ljubljani. Zbirka GeograFF I. Znanstvena založba Filozofske fakultete in Oddelek za geografijo, 87 str. Ljubljana 2008.}

To delo je izšlo kot prvi zvezek nove geografske knjižne zbirke, ki jo bosta skupaj izdajala Znanstvena založba in Oddelek za geografijo Filozofske fakultete, v njej pa bodo v obliki monografij objavljeni rezultati temeljnih, aplikativnih in drugih raziskav iz različnih geografskih panog. Prinaša rezultate preučevanja onesnaženosti zraka zaradi prometa v Ljubljani, ki ga je opravil Oddelek za geografijo v sodelovanju z Agencijo Republike Slovenije za okolje, finančno pa ga je podprla Mestna občina Ljubljana. Čeprav se avtor na začetku študije na kratko dotakne tudi drugih škodljivih snovi v zraku, nastalih z zgorevanjem pogonskih goriv $\mathrm{v}$ avtomobilih, se v nadaljevanju skoraj povsem omeji na onesnaževanje zaradi dušikovih oksidov. Velika večina jih nastane ravno v avtomobilskih motorjih, zato niso ustrezen predmet preučevanja zgolj zaradi škodljivosti, temveč lahko služijo kot odlični pokazatelji, kako daleč od cest segajo škodljivi vplivi prometa in kako se te škodljive snovi širijo po mestnem prostoru.

Avtor je knjigo smiselno razdelil na sedem poglavij, v katerih so jedrnato in pregledno predstavljene geografske značilnosti cestnega prometa $v$ Ljubljani, splošne značilnosti onesnaževanja ozračja zaradi prometa $\mathrm{z}$ različnimi škodljivimi snovmi (žveplov dioksid, trdni delci, ozon, benzen in dušikovi oksidi) in vremenske razmere v času merjenj. Ključni sta šesto in sedmo poglavje: šesto prikazuje glavne rezultate opravljenih meritev in njihovo sintezo s pomočjo prečnih profilov koncentracij, v sedmem pa so, kljub avtorjemu dvomu v hitro rešitev vse hujšega problema prometne onesnaženosti, predstavljeni številni predlogi, $\mathrm{s}$ katerimi bi morda lahko zajezili vse hujšo prometno gnečo v mestu in tudi naraščanje onesnaženosti zraka.

V prvem delu knjige so predstavljeni nekateri številčni podatki, nad katerimi bi se morala resnično zamisliti tako celotna mestna uprava kot prebivalci in obiskovalci glavnega mesta: znotraj mestne občine je dnevno opravljenih 1,2 milijona poti, od katerih jih $70 \%$ opravijo Ljubljančani in $30 \%$ drugi, vsak dan pripotuje v mesto od 90.000 do 120.000 ljudi, od tega dve tretjini $\mathrm{z}$ avtomobilom, $\mathrm{z}$ javnim potniškim prevozom znotraj mestne občine pa je opravljenih samo $14 \%$ vseh poti.

Onesnaževanje, ki ga povzroča tako intenziven cestni promet, je specifično tudi zaradi precejšnje odvisnosti od zunanjih okoliščin, tako od vremenskih razmer kot od razporeditve cest in izoblikovanosti/zazidanosti njihove neposredne okolice. To povzroča precejšnje težave pri merjenju onesnaženosti, saj zaradi zelo velikih razlik na majhne razdalje ni možno izvesti meritev na celotnem območju mesta. V tej raziskavi so se odločili za merjenje koncentracij 
dušikovega dioksida s pomočjo Palmesovih difuzivnih vzorčevalnikov, meritve pa so potekale tako v poletnem (od 25. avgusta do 14. septembra 2005) kot v zimskem času (od 24. januarja do 7. februarja 2006). Vzorčevalniki so bili razmeščeni tako, da so rezultati meritev omogočali izdelavo zelo zgovornih prečnih profilov koncentracij, kar je po mojem mnenju, poleg meritev samih, najpomembnejši in zelo uporaben rezultat te raziskovalne naloge. Ker je avtor zelo natančno pojasnil tudi prednosti in slabosti uporabljene metode, so dobljeni rezultati dovolj zanesljivi in zato neposredno uporabni.

Sicer se ve, da zdravju škodljiva stopnja onesnaženosti zaradi prometa ne sega daleč vstran od zelo prometne ceste, vendar pa se premalo zavedamo, da smo tudi v avtomobilu zelo izpostavljeni tem škodljivim snovem. Še manj pa je poznano, da se koncentracije dušikovih oksidov zelo močno povečajo na najbolj prometnih mestnih ulicah (avtor jih imenuje cestni koridorji), ki se zelo slabo prezračujejo zaradi sklenjene pozidave tik ob cesti na obeh straneh (v Ljubljani npr. Slovenska, Aškerčeva ali Poljanska cesta) in kjer so poleg voznikov in potnikov v avtomobilih močno ogroženi tudi drugi udeleženci (pešci in kolesarji) ter seveda tamkajšnji prebivalci.

Kljub zelo zgovornim rezultatom merjenj onesnaženosti zraka se zanimivo branje ne zaključi v posebno optimističnem tonu. Tudi po avtorjevem mnenju je rešitev samo ena: zmanjšanje prometa v mestnih središčih, vendar pa bomo v naših razmerah do tega prišli zelo zelo težko. Ogrinovo delo nas bo še bolj prepričalo, da je ob najbolj obremenjenih mestnih prometnicah onesnaževanje zraka prehudo (zlasti ob neugodnih vremenskih situacijah z brezvetrjem v trdovratnem jezeru hladnega zraka v dnu kotline), da je treba nekaj storiti (tudi domača in evropska zakonodaja zahtevata, da se sprejmejo načrti in programi za izboljšanje kakovosti zraka), a promet na mestnih ulicah še kar narašča, onesnaženost zraka pa ostaja (pre)visoka.

Karel Natek 